뇌전중모양방전 없이 뇌전중양 관류 단일광자방출 컴퓨터단충찰영 소견을 보이는 혈관조영술 유발 실어중 한자

송정윤 이서영 장재원

강원대학교 의학전문대학원 신경과학교실

\title{
Angiography-Induced Aphasia Presenting Seizure-Like Brain Perfusion Single Positron Emission Computed Tomography without Epileptiform Discharge
}

Jeong Yun Song, MD, Seo-Young Lee, MD, PhD, Jae-Won Jang, MD, PhD

Department of Neurology, Kangwon National University School of Medicine, Chuncheon, Korea

J Korean Neurol Assoc 39(4):362-365, 2021

Key Words: Coronary angiography, Aphasia, Cortical spreading depression

심혈관조영술은 흥통이나 심전도 또는 운동부하검사 등의 이상 이 있을 때 시행되는 허혈심질환의 진단을 위한 검사이다. 심혈관 센터에서 널리 시행되는 검사이지만, 혈관성 합병증, 경련, 아나필 락시스 반응 등 다양한 합병증을 발생시키기도 한다. ${ }^{1}$ 가장 흔한 혈관성 합병증은 색전에 의한 뇌경색이며, 의식 변화, 국소적인 운 동 또는 감각결손, 시야 이상, 외안근 마비, 실어증 등의 다양한 신경계증상을 동반할 수 있다. ${ }^{2}$ 저자들은 심혈관조영술에 의해 유 발되었으나 일과성 허혈발작(transient ischemic attack, TIA)이나 경련처럼 즉각적으로 호전되지 않고 지속적인 실어증을 보인 증례 를 경험하였기에 보고하고자 한다.

\section{중 례}

고혈압, 당뇨, 고지혈증 및 뇌경색 과거력이 있는 83 세 남자가 흥통을 주소로 입원하여 허혈심질환에 대한 검사로 입원 당일 심

Received May 3, 2021 Revised June 25, 2021

Accepted June 25, 2021

Address for correspondence: Jae-Won Jang, MD, PhD

Department of Neurology Kangwon National University School of Medicine, 1 Kangwondaehak-gil, Chuncheon 24341, Korea

Tel: +82-33-258-9174 Fax: +82-33-258-2103

E-mail: light26@kangwon.ac.kr
혈관조영술을 시행받았다. 심혈관조영술을 마치고 2시간 후 환자 는 갑작스러운 혼돈 상태를 보이며 언어기능에 문제가 생겼다. 주 변 사람들이 질문을 했을 때 현재의 대화의 맥락과 상관없는 대답 을 하고, 긴 질문은 한번에 이해하지 못하고 한참 동안 생각하는 듯한 모습 보이며 무슨 말인지 모르겠다고 대답하였다. 의사 표현 을 하지 못하고 짧은 단어만 표현할 수 있으며, 문장으로 말하지 못했다. 적절한 단어를 단어를 찾지 못하고, 제대로 읽지도 못하는 모습을 보였다.

증상 발생 당일 시행한 뇌 컴퓨터단층촬영 상에서는 이상 소견 은 관찰되지 않았다. 뇌 확산강조영상에서 1 개의 아주 작은 고신호 강도 병변이 확인되었으나 병소의 위치가 언어장애와 연관되지 않 는 우측 전두엽 피질이었다(Supplementary Fig.).

증상 발생 당시 활력징후는 안정적이었고, 시행한 혈액검사 결 과에서는 이상 소견이 없었다. 신경계진찰에서 의식 수준은 명료 하였으며, 언어기능평가에서 유창성 및 이해력의 저하가 나타나고 완전 실어증 양상을 보였다. 뇌신경검사, 운동 및 감각검사, 병적반 사검사는 정상이었다. 추가로 시행한 뇌 자기공명영상에서도 언어 능력과 관련된 영역의 혈관이상이나 구조적 문제는 없었으나 처음 확인되었던 확산강조영상에서의 병변과 TIA의 가능성을 고려하여 급성뇌경색에 대한 치료를 시작하였다.

입원 2 일째에도 증상은 같은 상태로 지속하였으며, 시행한 뇌파검 
사에서 뇌전증모양방전 없이 서파가 좌측 대뇌 반구에 국한되어 관찰되었다(Fig. A). 환자의 실어증은 입원 6일째까지 비슷한 양 상이었으며, 환자의 언어평가를 위해 6개의 소검사-그림 설명하기 (3점), 이름대기(4점), 이해하기(10점), 따라 말하기(3점), 읽기(7점), 쓰기(3점)-로 이루어진 실어증-신경언어장애 선별검사(screening test for aphasia and neurologic communication disorder, STAND) 를 시행하였다. STAND검사의 각 항목별 점수는 그림 설명하기 $0 / 3$ 점, 이름대기 $0 / 4$ 점, 이해하기 $0 / 10$ 점, 따라 말하기 $1 / 3$ 점, 읽기 $1 / 7$ 점, 쓰기 $0 / 3$ 점으로 총점은 $2 / 30$ 점이었다. 검사하는 동안 여러 번 반복해서 질문해야 했고, 대답하는 데 오래 걸렸다. 같은 날 시행한 뇌 단일광자방출컴퓨터단층촬영(single positron emission computed tomography, SPECT)에서는 좌측 측두엽과 두정엽 피질의
관류의 증가가 확인되었다(Fig. B).

1 주일에 걸쳐서 급성뇌경색 치료를 하면서 서서히 언어 유창성 및 이해력이 호전되어 입원 10 일째 STAND를 다시 시행하였을 때, 이름대기와 이해하기의 항목에서만 감점을 받았고 나머지 영 역에서의 감점 없이 총점 27/30점으로 호전되었다. 같은 날 추적 관찰한 뇌파검사에서도 좌측 후두엽의 서파가 관찰되었으나 처음 뇌파에 비해 호전된 양상이었다(Fig. C). 또한 입원 11일째 시행한 뇌관류 SPECT 결과상 이전에 관찰되었던 좌측 두정엽 및 측두엽 의 관류 증가 소견은 감소하였다(Fig. D). 환자는 실어증의 증상 없이 병 전 수준으로 회복되어 퇴원하였다.
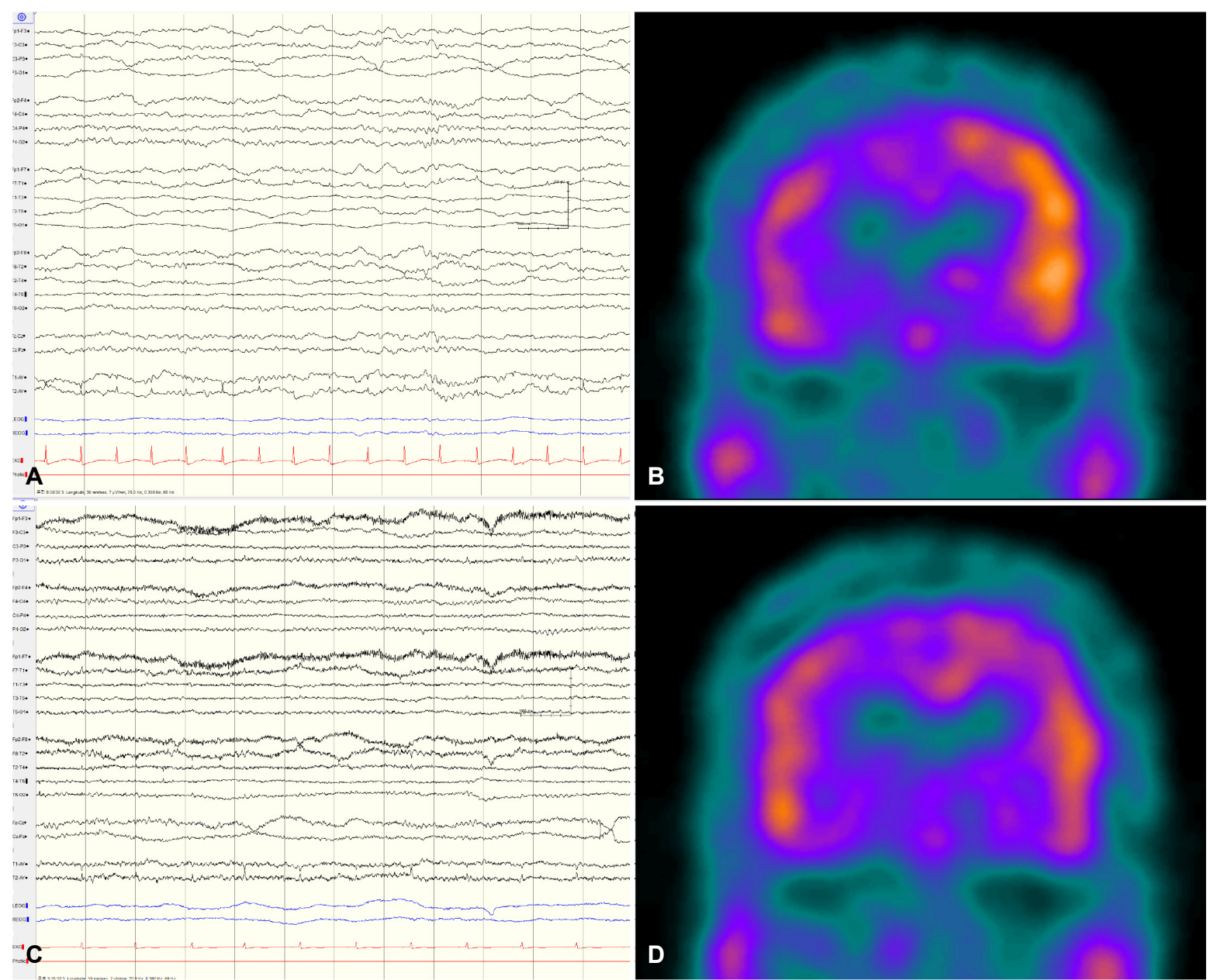

Figure. (A) Initial EEG of day 2 showed persistent lower amplitude delta slowing in left hemisphere. (B) Initial brain perfusion SPECT of day 4 showed increased perfusion in the left parietotemporal lobes. (C) Improved EEG was seen on day 11 although persistent lower amplitude delta slowing still existed. (D) Improved hyperperfusion in the left parietotemporal lobes on brain perfusion SPECT of day 11. EEG; electroencephalography, SPECT; single positron emission computed tomography. 


\section{고}

\section{찰}

급성뇌경색은 심혈관 카테터 시술 후 발생하는 가장 흔한 합병 증 중 하나이다. 이러한 급성뇌경색 또는 TIA의 경우, 뇌관류 SPECT에서 병소의 저관류 소견을 나타내고, 대개 뇌파검사에서 뇌전증모양방전이 나타나지 않는다. ${ }^{3}$ 또한 발생한 신경학적결손이 회복되는 데 비교적 오랜 시간이 걸리거나 영구적으로 증상이 남 는 경우가 많다. 급성뇌경색으로 인한 완전 실어증과 비교하였을 때, 본 증례에서는 증상이 6 일에 걸쳐 지속되었으며, 11 일 이상 경 과하면서 완전히 회복되었고, 뇌관류 SPECT에서 좌측 측두엽 영 역에 관류가 증가하였다는 점에서 차이가 있다. 따라서 뇌 영상검 사 결과와 임상 경과를 종합하였을 때 급성뇌경색에 부합된다고 보기 어렵다.

심혈관조영술의 드문 합병증으로 보고된 발작의 경우에는 뇌전 증모양방전을 포함한 뇌파 소견을 보이며, 증상이 서서히 발전 (evolving)하거나 변동(fluctuation)을 보이는 것이 특징이다. 또한 이전에 보고된 실어증 발작 증례들에서 뇌관류 SPECT는 좌측 측 두엽에서 과관류가 흔히 관찰되었다. ${ }^{4}$ 본 증례에서는 이와 비슷하 게 뇌관류 SPECT검사 결과 좌측 측두엽의 과관류가 확인되었지 만 뇌파검사에서 뇌전증모양방전은 나타나지 않았다는 점에서는 뇌전증 발작, 더 나아가 뇌전증지속상태의 가능성은 떨어지는 것 으로 판단하였다. 게다가 기존에 보고된 실어증 발작 증례와 비교 하였을 때, 즉각적이고 저명한 증상의 호전을 보이지 않았고, 항경 련제 투여 및 유발요인에 대한 적절한 치료에도 불구하고 서서히 수일에 걸쳐 실어증이 호전되는 양상을 보인 점으로 미루어 뇌전 증 발작 또는 뇌전증지속상태의 가능성은 낮다고 보았다. 또한 뇌 전증 발작 이후에 발생한 Todd마비(Todd's paralysis) 증상의 하나 로 설명하기에는 발작 후 증상(post ictal symptom)을 지속시킬만 한 임상적인 경련이 없었다.

혈관조영술 후에 발생하는 뇌병증은 실어증의 형태로 나타날 수 있으나 그 기전은 불분명하다. 혈관조영술로 유발된 뇌병증의 기 전에 대해 설명할 수 있는 하나의 가설은 편두통이나 외상성 뇌 손상 환자에서 나타나는 일시적인 신경학적결손에서 보이는 병태 생리 기전으로 알려진 피질확산성억제(cortical spreading depression)이다. 피질확산성억제는 유해 자극에 의한 세포 안팎의 이온 농도 기울기의 손상과 뉴런의 부종으로 나타나는 지속적인 확산 탈분극(spreading depolarization)에 의한 뇌의 전기적 활동성의 감 소를 의미한다. ${ }^{6}$ 따라서 뇌관류 SPECT에서 좌측 두정엽 및 측두 엽의 과관류를 보인 점과 해당 부위의 뇌전증모양방전 없이 서파 만 관찰된 뇌파검사 결과는 피질확산성억제와 일맥상통한다고 볼
수 있다. 기존에 보고된 동물 및 인간에서의 연구에 따르면 피질확 산성억제는 미세색전(microemboli), 전해질 불균형 등에 의해 촉 발될 수 있다고 알려져 있다. ${ }^{7}$ 따라서 본 증례의 경우에도 심혈관 조영술 과정에서 발생한 미세색전 또는 사용된 조영제에 의한 중 추신경계에서의 전해질 및 삼투 농도의 변화가 피질확산성억제를 촉발하여 이러한 현상을 일으켰을 가능성이 있다.

또한 이전에 보고된 대부분의 피질확산성억제 증례에서 신경학 적결손은 보통 수일 동안 지속되다가 서서히 호전되는 양상을 보 이고, 이후 완전히 회복되었다. 본 증례에서는 완전 실어증이 6일 간 유지되고, 이후 11 일에 걸쳐 완전히 회복되었다. 이러한 임상적 경과는 이전에 보고된 피질확산성억제의 증례들과 일치한다고 볼 수 있다.

본 증례에서는 언어장애에 대한 평가 시 한국판 웨스턴 실어증 검사를 시행하지 못하고 STAND로 대체한 한계점이 있었다. 또한, 뇌파와 SPECT를 시행한 시기가 2일의 간격으로 시행되었기에 각 검사 시행 시기의 차이로 인해 검사 결과 간 불일치 소견으로 나 왔을 가능성을 배제할 수 없다. 하지만 두 검사를 시행할 때 환자 의 임상 증상은 완전 실어증 형태로 동일한 양상을 지속적으로 보 이고 있었으며, 증상이 완전히 호전된 후 추적 관찰로 시행한 동 일한 두 검사에서 증상과 마찬가지로 검사 결과도 호전된 양상을 보였다.

본 증례는 혈관조영술로 유발된 뇌병증이 허혈 뇌졸중 또는 발 작 동반의 증거 없이 완전 실어증으로 나타난 사례이다. 이 증례에 서 뇌파검사 상 뇌전증모양방전은 없었으나 미만성 서파가 좌측 대뇌반구에 국한되어 관찰되고, 뇌관류 SPECT에서 해당 부위에 과관류 소견이 확인되었다. 이러한 검사 결과들 및 임상 경과를 고 려하였을 때, 급성뇌경색 또는 TIA에 의한 완전 실어증과 잘 맞지 않으며, 이전에 보고된 실어증 발작에도 부합한다고 보기 어렵다. 저자들은 본 증례의 발생 기전이 심혈관조영술에 의해 유발된 피 질확산성억제와 연관되어 있을 것이라고 생각하여 이를 보고하는 바이다.

\section{REFERENCES}

1. Choo WS, Barakath BA, Tan BK, Ismail O. A rare complication of percutaneous coronary artery intervention. Heart Asia 2010;2:130-132.

2. Harada Y, Kairamkonda SR, Ilyas U, Pothineni NVK, Samant RS, Shah VA, et al. Pearls \& Oy-sters: contrast-induced encephalopathy following coronary angiography: a rare stroke mimic. Neurology 2020;94:e2491-e2494.

3. Martín A, Macé E, Boisgard R, Montaldo G, Thézé B, Tanter M, et al. Imaging of perfusion, angiogenesis, and tissue elasticity after stroke. $J$ Cereb Blood Flow Metab 2012;32:1496-1507. 
4. Kim HY, Shon YM, Seo DW, Na DL. A case of aphasic status with brain 99m-tc ethyl cysteinate diethylester single photon emission computed tomography demonstrating focal hyperperfusion. J Korean Neurol Assoc 2000;18:333-336.

5. Phi JH, Lee SJ, Kang HS, Kim JE, Kim SK, Cho WS, et al. Postoperative transient neurologic dysfunction: a proposal for pathophysiology. $J$
Clin Neurol 2018;14:393-400.

6. Dreier JP. The role of spreading depression, spreading depolarization and spreading ischemia in neurological disease. Nat Med 2011;17: 439-447.

7. Charles AC, Baca SM. Cortical spreading depression and migraine. Nat Rev Neurol 2013;9:637-644. 